\title{
$\widehat{A}$ Madridge \\ madridge Journal of Case Reports and Studies
}

Research Article

Open Access

\section{Dermoscopy of Nail Fold Capillaries in Connective Tissue Diseases}

\author{
Younes Barbach, Mohammed Chaouche, Abdellah Dah Cherif, Sara Elloudi, Hanane Baybay, and Fatima Zahra Mernissi \\ Department of Dermatology, Hassan II University Hospital, Morocco
}

\section{Article Info}

*Corresponding author:
Younes Barbach
Doctor
Department of Dermatology
Hassan II University Hospital
Morocco
E-mail: dr.younes2011@gmail.com

Received: March 19, 2019

Accepted: March 25, 2019

Published: March 29, 2019

Citation: Barbach $Y$, Chaouche $M$, Cherif $A D$, Elloudi $S$, Baybay $H$, Mernissi $F Z$. Dermoscopy of Nail Fold Capillaries in Connective Tissue Diseases. Madridge J Case Rep Stud. 2019; 3(1): 130-131. doi: $10.18689 /$ mjcrs-1000132

Copyright: @ 2019 The Author(s). This work is licensed under a Creative Commons Attribution 4.0 International License, which permits unrestricted use, distribution, and reproduction in any medium, provided the original work is properly cited.

Published by Madridge Publishers

\begin{abstract}
Background: The periungual dermoscopy is a non-invasive tool to study the qualitative and quantitative microcirculation at the level of proximal fold. It is increasingly used in dermatology in the study of systemic diseases.
\end{abstract}

Materiels and Methods: We describe the dermoscopic periungual appearance of 153 patients followed for various systemic diseases in the dermatology department of $\mathrm{CHU}$ HASSAN II in Fes, while comparing our results with those of the literature. The examination was performed with a photofinder dermoscope then dermlite by simple transillumination of the cutaneous epithelium illuminated by the dermoscope light.

Discussion: Dermoscopy makes it easy to distinguish a normal capillaroscopic landscape during primary Raynaud's phenomenon (RP), from a sclerodermic landscape reflecting organic microangiopathy specific to scleroderma, dermatomyositis or mixed connective tissue or overlap. Periungual dermoscopy can also be used to assess the risk of digital ulcers and visceral complications in patients with scleroderma.

Keywords: Dermoscopy; Systemic Disease; Nail Fold; Capillaries; Raynaud Phenomenon.

\section{Introduction}

The systematic use of dermoscopy can replace capillaroscopy for the detection of nail abnormalities in systemic diseases and integrate into standard clinical practice because it provides the same information. It is a simple and fast non-invasive tool, the equipment is portable and inexpensive.

\section{Materials and Methods}

An observational prospective study has been designed from February 2014 to December 2018 in the dermatology department of CHU HASSAN II in Fes. We initially used a photoFinder dermoscope then dermlite. The evaluation was performed on the back of the third and fourth finger, both hands of our patients by transillumination of the cutaneous epithelium. After the patient has been in a room at $20-23^{\circ} \mathrm{C}$ for $15-20 \mathrm{~min}$ and has not used tobacco or received a recent manicure before consultation, fingers affected by recent local trauma have not been analyzed.

\section{Results}

We collected 153 patients including 136 women and 17 men, the average age of our sample was 38 years, 52 patients with a Raynaud phenomenon with an average duration of 3.75 years. A sclerodermiform pattern (Figureure 1) was found in: $75 \%$ of 32 patients, $45 \%$ of 40 patients, $23,33 \%$ of 60 patients, $47 \%$ of 17 patients, and in half of patients with 
systemic sclerosis dermatomyositis, lupus erythematosus, mixed connective tissue disease and finally Sjogren's syndrome (Table 1).

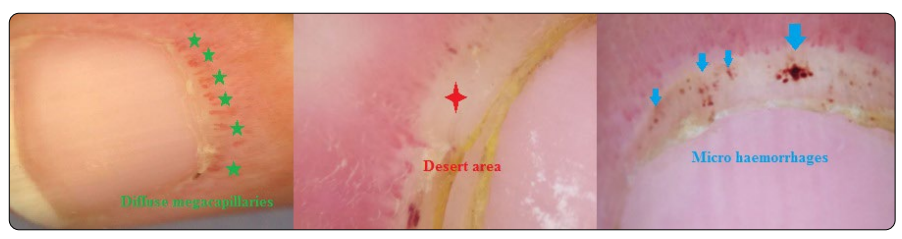

Figureure 1. The main dermoscopic signs found in a sclerodermiform pattern in our patients.

Table 1. The evaluation of periungual dermoscopy in our study.

\begin{tabular}{|c|c|c|c|c|c|c|c|}
\hline & 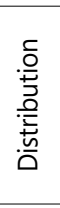 & 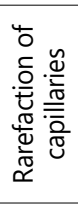 & 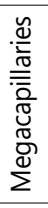 & 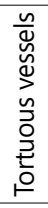 & 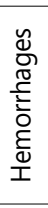 & 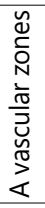 & $\underset{\widetilde{D}}{\stackrel{5}{ \pm}}$ \\
\hline $\begin{array}{l}\mathrm{SCS} \\
\mathrm{N}=32\end{array}$ & 19 & 14 & 15 & 18 & 18 & 12 & 24 (75\%) \\
\hline $\begin{array}{l}\mathrm{DM} \\
\mathrm{N}=40\end{array}$ & 11 & 9 & 10 & 13 & 10 & 5 & 18 (45\%) \\
\hline $\begin{array}{l}\text { LES } \\
\mathrm{N}=56\end{array}$ & 11 & 7 & 14 & 18 & 17 & 2 & $14(23,3 \%)$ \\
\hline $\begin{array}{l}\text { Mixed connective } \\
\mathrm{N}=17\end{array}$ & 10 & 6 & 5 & 10 & 7 & 4 & $8(47 \%)$ \\
\hline $\begin{array}{l}\text { Gougerot Sjogren } \\
\mathrm{N}=4\end{array}$ & 1 & 1 & 1 & 2 & 1 & 0 & $2(50 \%)$ \\
\hline
\end{tabular}

\section{Discussion}

The sensitivity and specificity of dermoscopy in the diagnosis of systemic diseases has been proven in several studies such as that of Bergman et al. [1], carried out in 106 patients and 170 controls, and which objectified a sclerodermiform pattern in 19/27 patients. Patients with scleroderma (70\%), 7/11 (64\%) of those with dermatomyositis, 4/8 (50\%) with Sharp syndrome, 2/38 (5\%) with RP alone, and no subject controls. Periungual dermoscopy in systemic diseases looks for the same abnormalities as in capillorscopy, namely megacapillaries, dilated and branched vessels, haemorrhages and avascular zones in advanced forms, notably in systemic scleroderma [2]. A sclerodermiform pattern is defined (according to Maricq criteria modified by Bergman et al.) [1,3]. Presence of at least 2 following anomalies: megacapillaries, micro haemorrhages, architectural disorganization of the capillary distribution, moderate or extensive loss of the capillaries, tortuous capillaries, crossed or branched. Several studies in the literature have analyzed the perungual dermoscopy in systemic diseases including that of Bergman, Beltran and Tsutomu $[1,4,5]$. Our results were almost similar for the sclerodermiform pattern in systemic scleroderma and mixed connective tissue with a percentage of $\approx 70 \%$ and $50 \%$ respectively, a lower percentage for dermatomyositis (45\%), and more important for lupus erythematosus (23\%), 85\% compared to other studies (Table 2). Sclerodermiform pattern analysis in Sjogren Goujerot syndrome has never been described in the literature found in $50 \%$ of our patients. However, there are several factors that limit the penetration of the light beam, thus preventing the visualization of the loops and make the examination difficult are the skin pigmentation, the epidermal thickening of the manual worker, the recent care of manicure, the application of varnish or henna on periungual areas.

Table 2. The results of our study compared to those of the literature.

\begin{tabular}{|l|c|c|c|c|}
\hline & $\begin{array}{c}\text { Study of } \\
\text { Bergman }\end{array}$ & $\begin{array}{c}\text { Study of } \\
\text { Beltran }\end{array}$ & $\begin{array}{c}\text { Study of } \\
\text { Tsutomu }\end{array}$ & OUR Study \\
\hline SSC & $70.4 \%(n=27)$ & $76,9 \%(n=26)$ & $70,4 \%(n=62)$ & $75 \%$ \\
\hline DM & $63.6 \%,(n=11)$ & & $63,6 \%(n=10)$ & $45 \%$ \\
\hline LES & $4,5 \%,(n=22)$ & & $14,3 \%(n=28)$ & $23,33 \%$ \\
\hline Mixed connective & $50 \%(n=8)$ & & & $47 \%$ \\
\hline
\end{tabular}

\section{Conclusion}

Dermoscopy is a powerful diagnostic tool, reproducible, non-invasive and very inexpensive. A small training in dermoscopy allows to recognize the different hair patterns and thus help the clinician whether dermatologist, internist or rheumatologist to differentiate a primary Raynaud from a secondary one, make an early diagnosis of scleroderma. Its use as a prognostic tool in the short or long term to predict peripheral or pulmonary vascular complications during scleroderma, is in full development.

\section{Conflict of Interest}

None

\section{References}

1. Bergman R, Sharony L, Schapira D, Nahir MA, Balbir-Gurman A. The handheld dermatoscope as a nail-fold capillaroscopic instrument. Arch Dermatol. 2003; 139(8): 1027-1030. doi: 10.1001/archderm.139.8.1027

2. Hasegawa M. Dermoscopy findings of nail fold capillaries in connective tissue diseases.JDermatol.2011;38(1):66-70.doi:10.1111/j.1346-8138.2010.01092.x

3. Maricq HR, Harper FE, Khan MM, Tan EM, LeRoy EC. Microvascular abnormalities as possible predictors of disease subsets in Raynaud phenomenon and early connective tissue disease. Clin Exp Rheumatol. 1983; 1(3): 195-205.

4. Beltrán E, Toll A, Pros A, Carbonell J, Pujol RM. Assessment of nailfold capillaroscopy by $x 30$ digital epiluminescence (dermoscopy) in patients with Raynaud phenomenon. Br J Dermatol. 2007; 156(5): 892-898. doi: 10.1111/j.1365-2133.2007.07819.x

5. Ohtsuka T, Tamura T, Yamakage A, Yamazaki S. The predictive value of quantitative nailfold capillary microscopy in patients with undifferentiated connective tissue disease. Br J Dermatol. 1998; 139(4): 622-629. 